\title{
Sistem Pendukung Keputusan Pemilihan Siswa Peserta Olimpiade Pada Jenjang Sekolah Dasar Di Kecamatan Gunung Maligas Dengan Menggunakan AHP
}

\author{
Erozeki Sialagan $^{1}$, Rahmat Widia Sembiring ${ }^{2}$, Suhada $^{3}$ \\ ${ }^{I}$ Mahasiswa Program Studi Sistem Informasi, STIKOM Tunas Bangsa, Pematangsiantar \\ ${ }^{2,3}$ Dosen AMIK Tunas Bangsa, Pematangsiantar \\ lerozekisiallagan@gmail.com, ${ }^{2}$ rahmatws@gmail.com, ${ }^{3}$ suhada.atb@gmail.com
}

\begin{abstract}
This study aims to assist relevant parties in making selections in the selection of olympic students at the Elementary School Level in Gunung Maligas District. The method used is the AHP method. Source of research data obtained by observing and interviewing the school. The research data samples were four elementary schools in Gunung Maligas subdistrict, among others: 1) SDN 096780 Kampung tape, 2) SDN 097806 Kabupaten Simalungun, 3) SDN 091263 Karang Sari and 4) SDN 098145 Karang Sari. The assessment criteria used as a basis for assessments include: Olympic Experience, Intelligence, Academic Ability (Science Report Score or Mathematics) and Olympic Capabilities. The results of the study showed that alternative 4 with a value of 0.356 (first rank) was recommended by Olympic student participants.
\end{abstract}

Keywords: SPK, AHP method, Elementary School, ranking, Olympic Participants

\begin{abstract}
Abstrak
Penelitian ini bertujuan untuk membantu pihak terkait dalam melakukan seleksi pada pemilihan siswa olimpiade pada Jenjang Sekolah Dasar Di Kecamatan Gunung Maligas. Metode yang digunakan adalah metode AHP. Sumber data penelitian diperoleh dengan cara melakukan observasi dan wawancara terhadap pihak sekolah. Sampel data penelitian adalah empat Sekolah Dasar (SD) di kecamatan Gunung Maligas antara lain: 1) SDN 096780 Kampung tape, 2) SDN 097806 Kabupaten Simalungun, 3) SDN 091263 Karang Sari dan 4) SDN 098145 Karang Sari. Kriteria penilaian yang digunakan sebagai dasar penilaian antara lain: Pengalaman Olimpiade, Intelligensi, Kemampuan Akademik (Nilai Rapor IPA atau Matematika) dan Kemampuan Olimpiade. Hasil dari penelitian menunjukkan bahwa alternatif 4dengan nilai 0,356 (peringkat pertama) sebagai rekomendasi peserta siswa olimpiade.
\end{abstract}

Kata Kunci: SPK, metode AHP, Sekolah Dasar, perangkingan, Peserta Olimpiade

\section{Pendahuluan}

Olimpiade Sains Nasional merupakan ajang berkompetisi dalam bidang sains bagi para siswa pada jenjang Sekolah Dasar (SD), Sekolah Menengah Pertama (SMP), dan Sekolah Menengah Atas (SMA) di Indonesia. Siswa yang mengikuti Olimpiade Sains Nasional adalah mereka yang telah lolos seleksi tingkat kabupaten dan provinsi yang merupakan siswa-siswa terbaik dari provinsinya masing-masing. Hal ini juga merupakan salah satu program pemerintah dalam meningkatkan kualitas sumber daya manusia melalui Departemen Pendidikan Nasional yakni dengan menyelenggarakan Olimpiade Sains Nasional (OSN).

Penyelenggaraan Olimpiade Sains Nasional tersebut secara umum bertujuan untuk meningkatkan wawasan pengetahuan, kemampuan kreatifitas dan motivasi meraih prestasi terbaik dengan kompetisi yang sehat. Dalam Olimpiade Sains Nasional tingkat SD/MI tersebut mempertandingkan dua mata pelajaran yaitu matematika dan IPA yang 
dilakukan secara berkala satu tahun sekali dengan siswa para siswa sekolah dasar. Untuk dapat mengikuti Olimpiade Sains sampai tingkat nasional para siswa harus lolos pada olimpiade tingkat kabupaten dan propinsi.

Setiap SD Negeri Kab. Simalungun, Prov. Sumatera Utara khususnya di kecamatan gunung maligas selalu mengirimkan siswanya setiap tahun untuk mengikuti olimpiade pada tingkat kabupaten. Dari pengalaman beberapa tahun sebelumnya, dalam pemilihan siswa terdapat beberapa permasalahan yakni dalam pemilihan siswa-siswa olimpiade, Masalah Yang selalu terjadi adalah adanya penolakan dari pihak guru atau sekolah lain yang ada di kec.Gunung Maligas karena siswa yang diunjuk untuk mewakili ke tingkat kabupaten hanya dinilai berdasarkan nilai akademik, padahal soal-soal olimpiade sains yang di ujikan baik pada tingkat kabupaten, propinsi dan nasional diperlukan faktor-faktor yang lain di antaranya yaitu tingkat intelegensi dan pengalaman dalam mengikuti olimpiade sains sebelumnya. Disamping permasalahan diatas, pihak guru dalam pemilihan siswa olimpiade tidak memperhatikan semua faktor sehingga hasilnya kurang maksimal.

Dalam hal ini peneliti menggunakan empat data Sekolah Dasar di kecamatan gunung maligas antara lain: 1) SDN 096780 Kampung tape kec. Gunung maligas, Kab.Simalungun, Provinsi sumatera Utara, 2) SDN 097806 Kabupaten Simalungun, Jalan Anjangsana Huta 1 Karang Rejo, 3) SDN 091263 Karang Sari. Jl. Handayani No 81 Karang Anyar Kec.Gunung Maligas, Kab.Simalungun, Provinsi Sumatera Utara dan 4) SDN 098145 Karang Sari, Jl.Duriat Huta 2 Karang Anyar Kec.Gunung Maligas, Kab.Simalungun, Provinsi Sumatera Utara. Oleh karena itu perlu dirancang suatu sistem pendukung keputusan yang di harapkan dapat membantu pengambil keputusan dalam mendapatkan informasi untuk menentukan siswa-siswa olimpiade tingkat sekolah dasar yang tepat dalam mengikuti olimpiade sains. Hal ini diperlukan untuk menganalisa dengan seksama siswa olimpiade sehingga mampu bersaing dengan siswa dari sekolah dasar yang lain. Diharapkan penelitian ini dapat membantu dalam proses pemilihan calon siswa olimpiade sains di Kecamatan Gunung Maligas dan melakukan analisis dengan menggunakan metode Analytical Hierarchy Process (AHP) sehingga menjaring calon siswa yang betul-betul berkompeten dalam bidangnya masing-masing.

\section{Metode Penelitian}

\subsection{Sistem Pendukung Keputusan}

Sebuah aplikasi (Decision Support System) yang mulai berkembang pada tahun 1970. Untuk memberikan pengertian yang lebih mendalam, akan diuraikan beberapa definisi mengenai SPK yang dikembangkan oleh beberapa ahli dengan didukung oleh sebuah sistem informasi berbasis komputer dapat membantu seseorang dalam meningkatkan kinerjanya dalam pengambilan keputusan [1][2][3].

\subsection{Metode Analytical Hierarchy Process (AHP)}

Pembobotan additive yang merupakan model AHP pertama yang dikembangkan oleh Thomas L. Saaty yang disebut additive karena operasi aritmatika untuk mendapatkan bobot totalnya adalah penjumlahan. Dalam metode AHP, ada tiga prinsip pokok yang harus diperhatikan, yaitu [4]:

1. Prinsip penyusunan hirarki

2. Prinsip menentukan prioritas

3. Prinsip konsistensi logis

\subsection{Algoritma Sistem}

Algoritma yang digunakan dalam penelitian ini adalah salah satu bagian dari algoritma Sistem Pendukung Keputusan (SPK) yaitu metode Analytical Hierarchy Process (AHP).Gambar flowchartAnalytical Hierarchy Process (AHP)dapat dilihat pada gambar 1. 


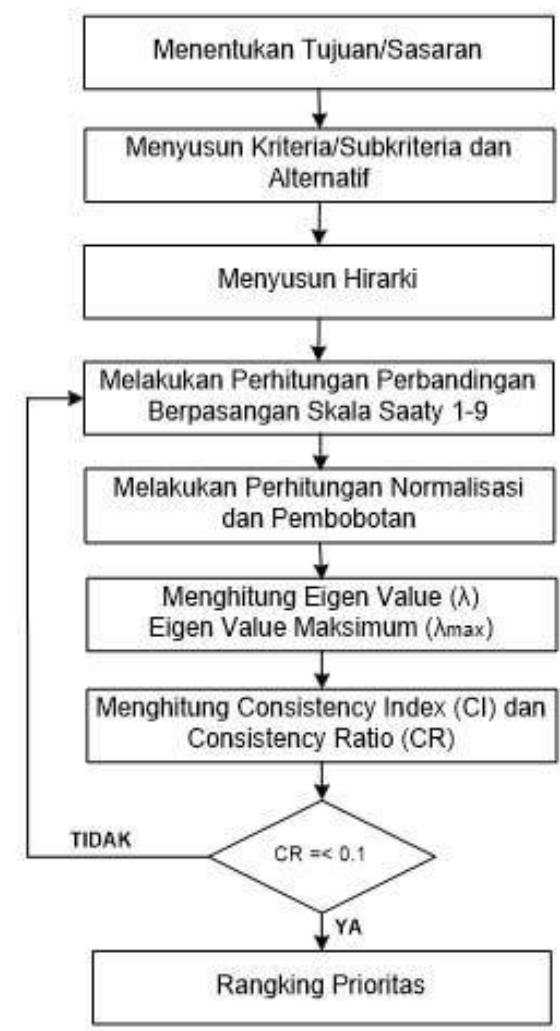

Gambar 1. FlowchartAnalytical Hierarchy Process (AHP)

Berikut uraian dari flowchart standar pembentukan AHP tersebut [5].:

a. Mendefinisikan permasalahan dan menetukan tujuan/pengetahuan yang ingin dicapai.

b. Menyusun stuktur hirarki denga urutan paling atas adalah tujuan yang diharapkan (goal decision), kemudian dikikuti kriteri (bisa dilanjutkan ke sub-kriteria) dan level terbawah adalah alternatif.

c. Menyusun matriks perbandingan berpasangan (pairwise comparison) untuk setiap kriteria/sub-kriteria dan alternatif yang telah ditentukan.

d. Teknik perbandingan berpasangan menggunakan skala prioritas untuk kriteria terpilih menggunakan Skala Saaty 1-9 berikut.

Tabel 1 Skala Saaty untuk Perbandingan Berpasangan

\begin{tabular}{cl}
\hline $\begin{array}{c}\text { Intensitas } \\
\text { Pentingnya }\end{array}$ & \multicolumn{1}{c}{ Definisi } \\
\hline 1 & Kedua elemen/alternatif sama pentingnya (equal) \\
3 & Elemen A sedikit lebih esensial dari elemen B (moderate) \\
5 & Elemen A lebih esensial dari elemen B (strong) \\
7 & Elemen A jelas lebih esensial dari elemen B (very strong) \\
9 & Elemen A mutlak lebih esensial dari elemen B (very strong) \\
$2,4,6,8$ & Nilai-nilai antara diantara dua petimbangan yang berdekatan \\
\hline
\end{tabular}

Matriks untuk elemen $a_{i j}$ mendapat nilai $x$ sehingga untuk elemen $a_{i j}$ (kebalikanya) mendapat nilai $1 / x$ sehingga bersifat reciprocal

e. Melakukan proses normalisasi yaitu operasi baris dengan membagi nilai matriks $a_{\mathrm{ij}}$ dengan nilai total matriks dalam satu kolom (n) dan operasi kolon untuk mendapatkan nilai pembobotan $\left(\mathrm{w}_{\mathrm{i}}\right)$

$$
W_{i}=\sum_{i-1}^{n} a_{i j} / n
$$


$\underline{\text { Ket }}$ :

$\mathrm{W}_{\mathrm{i}}$ : nilai pembobotan

$\mathrm{A}_{\mathrm{ij}} / \mathrm{n}$ : matriks normalisasi baris

f. Menghitung eigen vector $(\lambda)$ dan eigen value maximum $\left(\lambda_{\max }\right)$

$$
\begin{aligned}
& \lambda_{\mathrm{i}}=\sum_{i=1}^{n} a_{i j} / w_{i} \\
& \lambda_{\max }=\sum_{i=1}^{n}\left(a_{i j} / w_{i}\right) / n
\end{aligned}
$$

g. Menguji konsistensinya dengan menggunakan consistency index (CI)

$$
\mathrm{CI}=\frac{\left(\lambda_{\max }-n\right)}{(n-1)}
$$

$\underline{\text { Ket }}$ :

$\overline{\lambda_{\max }}$ : eigen value maximum

n : jumlah matriks

h. Menghitung Consistency Ratio (CR)

Saaty (2008) menetaokan nilai CR $\leq 10 \%$ untuk standar data konsistensi bisa diterima dan jika $\mathrm{CR} \geq 10 \%$ maka data tidak konsisten sehingga dilakukan ulang pengambilan data untuk perbandingan berpasangan.

Rumus yang dipakai adalah :

$$
\mathrm{CR}=\frac{\mathrm{CI}}{\mathrm{IR}}
$$

Ket:

CR: Consistency Ratio

RI : Random Consistency Index

Tabel 2. Random Consistency Index

\begin{tabular}{ccccccccccc}
\hline $\mathbf{n}$ & 1 & 2 & 3 & 4 & 5 & 6 & 7 & 8 & 9 & 10 \\
RI & 0 & 0 & 0,58 & 0,9 & 1,12 & 1,24 & 1,32 & 1,41 & 1,45 & 1,49 \\
\hline
\end{tabular}

i. Hasil perangkingan

Setelah menghitung Consistency Ratio (CR), langkah terakhir ialah mencari urutan atau perangkingan dari seluruh alternatif berdasarkan kriteria yang digunakan.

\section{Hasil Dan Pembahasan}

\subsection{Analisis Kriteria dan Alternatif}

Proses seleksi dilakukan dengan kriteria penilaian yang telah ditentukan pihak sekolah dalam mengirim calon siswa untuk mengikuti olimpiade. Proses seleksi dilakukan mulai kelas 4, 5 dan 6 dimana setiap kelas terdiri dari beberapa calon yang akan diseleksi untuk diambil 1 orang per kelas mewakili SD tersebut. Pada penelitian ini, sampel yang diambil adalah siswa kelas 4 yang terdiri dari 4 peserta calon siswa olimpiade pada Jenjang Sekolah Dasar Di Kecamatan Gunung Maligas. Data kriteria penelitian yang didapatkan dari hasil observasi dapat dilihat pada Tabel di bawah ini :

Tabel 3. Kriteria Penilaian

\begin{tabular}{lll}
\hline No & Kriteria & \multicolumn{1}{c}{ Keterangan } \\
\hline 1 & PO & Pengalaman Olimpiade \\
2 & IQ & Intellegensi \\
3 & KA & Kemampuan Akademik (Nilai Rapor IPA atau Matematika \\
4 & KO & Kemampuan Olimpiade \\
\hline
\end{tabular}

Berdasarkan table 3. penilaian dilakukan dengan keadaan yang sebenarnya yang direpresentasikan dengan penilaian Skala Saaty untuk perbandingan berpasangan tiap kriteria. Adapun penilaian setiap kriteria adalah sebagai berikut:

Pada matriks kriteria terlihat perbandingan berpasangan untuk Pengalaman Olimpiade (K1) dengan Inteligensi (K2) terlihat bahwa K1 Nilai-nilai antara di antara dua pertimbangan yang berdekatan(2) dengan K2. Demikian pula K1 terhadap Kemampuan 
Akademik (K3), K1 dianggap sedikit lebih penting (3) dibandingkan dengan K3.Namun, Kemampuan Olimpiade (K4) dianggap lebih penting (5) dibandingkan dengan Pengalaman Olimpiade (K1). K2 saat dibandingkan dengan K3 menunjukkan tingkat kepentingan dianggap lebih penting (5) dibandingkan K3, dan Nilai-nilai antara di antara dua pertimbangan yang berdekatan (2) antara K2 dan K4.Demikian pula degan K4 dianggap lebih penting (5) dibandingkan K3.

Setelah proses pembobotan kriteria ditentukan, selanjutnya menentukan data alternatif calon siswa olimpiade. Data penelitian yang diguakan adalah data calon siswa peserta olimpiade pada Jenjang Sekolah Dasar Di Kecamatan Gunung Maligas pada tabel di bawah ini :

Tabel 4. Data alternatif peserta Sekolah Dasar Di Kec. Gunung Maligas

\begin{tabular}{|c|c|c|c|c|c|c|c|}
\hline No & Nama & JK & NISN & $\begin{array}{l}\text { Tempat } \\
\text { Lahir }\end{array}$ & $\begin{array}{l}\text { Tanggal } \\
\text { Lahir }\end{array}$ & Agama & Alamat \\
\hline 1 & $\begin{array}{c}\text { Alesha Dafiyah } \\
\text { Siahaan }\end{array}$ & $\mathrm{P}$ & 0098945171 & Simalungun & $2009-10-27$ & Islam & $\begin{array}{c}\text { Karang } \\
\text { Sari }\end{array}$ \\
\hline 2 & $\begin{array}{c}\text { Alisya Devi } \\
\text { Ardyan }\end{array}$ & $\mathrm{P}$ & 0099668303 & Karang Sari & $2009-12-30$ & Islam & $\begin{array}{c}\text { Karang } \\
\text { Sari }\end{array}$ \\
\hline 3 & Anisa Ramdhani & $\mathrm{P}$ & 0094963092 & $\begin{array}{l}\text { Pematang } \\
\text { Siantar }\end{array}$ & 2009-08-18 & Islam & $\begin{array}{c}\text { Karang } \\
\text { Sari }\end{array}$ \\
\hline 4 & $\begin{array}{c}\text { Asyanna Siringo } \\
\text { Ringo }\end{array}$ & $\mathrm{P}$ & 0082740511 & Karang Sari & 2008-08-06 & Katholik & $\begin{array}{c}\text { Karang } \\
\text { Sari }\end{array}$ \\
\hline
\end{tabular}

\subsection{Analisis Menggunakan Metode AHP}

Di dalam sistem pendukung keputusan ini, nilai yang diterima atau dimasukkan ke dalam sistem adalah berdasarkan pilihan dari pengguna sistem atau pengambil keputusan, kriteria yang digunakan dapat disesuaikan dengan kebutuhan seleksi setiap calon. Sebagai contoh dari pengambil keputusan menggunakan empat kriteria untuk seleksi pemilihan siswa olimpiade pada Jenjang Sekolah Dasar Di Kecamatan Gunung Maligas, yaitu:

1. $\mathrm{K} 1=$ Pengalaman Olimpiade

2. $\mathrm{K} 2=$ Intelligensi

3. $\mathrm{K} 3=$ Kemampuan Akademik (Nilai Rapor IPA atau Matematika)

4. $\mathrm{K} 4=$ Kemampuan Olimpiade

Kemudian pengambil keputusan memilih nilai dari perbandingan berpasangan diperlihatkan pada tabel dibawah:

Tabel 5. Skala Perbandingan Berpasangan Kriteria

\begin{tabular}{|c|c|c|c|c|c|c|c|c|c|c|c|c|c|c|c|c|}
\hline Kriteria & 98 & 7 & 6 & 5 & 4 & 3 & 2 & 1 & 2 & 3 & 4 & 5 & 6 & 7 & 8 & Kriteria \\
\hline K1 & & & & & & & & & $\mathrm{v}$ & & & & & & & $\mathrm{K} 2$ \\
\hline K1 & & & & & & V & & & & & & & & & & K3 \\
\hline K1 & & & & & & & & & & & & $\mathrm{v}$ & & & & K4 \\
\hline K2 & & & & $\mathrm{v}$ & & & & & & & & & & & & K3 \\
\hline $\mathrm{K} 2$ & & & & & & & & & & & $\mathrm{v}$ & & & & & K4 \\
\hline $\mathrm{K} 3$ & & & & & & & & & & & & $\mathrm{v}$ & & & & K4 \\
\hline
\end{tabular}

Pada tabel 5, dapat dijelaskan pada matriks kriteria terlihat perbandingan berpasangan untuk Pengalaman Olimpiade (K1) dengan Inteligensi (K2) terlihat bahwa K1 Nilai-nilai antara di antara dua pertimbangan yang berdekatan (2) dengan K2. Demikian pula K1 terhadap Kemampuan Akademik (K3), K1 dianggap sedikit lebih penting (3) dibandingkan dengan K3.Namun, Kemampuan Olimpiade (K4) dianggap lebih penting (5) dibandingkan dengan Pengalaman Olimpiade (K1).K2 saat dibandingkan dengan K3 menunjukkan tingkat kepentingan dianggap lebih penting (5) dibandingkan K3, dan Nilai-nilai antara di antara dua pertimbangan yang berdekatan (2) antara K2 dan K4.Demikian pula degan K4 dianggap lebih penting (5) dibandingkan K3. Dari tabel diatas didapatkan matriks perbandingan berpasangan sebagai berikut: 


$$
\left\{\begin{array}{llll}
1 & \frac{1}{2} & 3 & \frac{1}{5} \\
2 & 1 & 5 & \frac{1}{4} \\
\frac{1}{3} & \frac{1}{5} & 1 & \frac{1}{5} \\
5 & 4 & 5 & 1
\end{array}\right\}
$$

\section{a. Menghitung bobot kriteria}

1. Normalisasi matrik (A) dan menghitung vector bobot

$$
\mathrm{A}=\left\{\begin{array}{cccc}
1 & \frac{1}{2} & 3 & \frac{1}{5} \\
2 & 1 & 5 & \frac{1}{4} \\
1 & \frac{1}{5} & 1 & \frac{1}{5} \\
\frac{3}{5} & 4 & 5 & 1
\end{array}\right\}
$$

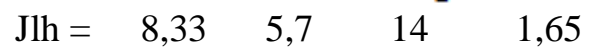

Setelah itu lakukan normalisasi dengan cara:
$\mathrm{A}_{1,1}=1 / 8,33$
$=0,12$
$\mathrm{A}_{1,3}=3 / 14$
$=0,214$
$\mathrm{A}_{2,1}=2 / 8,33$
$=0,24$
$A_{2,3}=5 / 14$
$=0,357$
$\mathrm{A}_{3,1}=(1 / 3) / 8,33=0,04$
$\mathrm{A}_{3,3}=1 / 14$
$=0,071$
$\mathrm{A}_{4,1}=5 / 8,33$
$=0,6$
$\mathrm{A}_{4,3}=5 / 14$
$=0,357$
$\mathrm{A}_{1,2}=(1 / 2) / 5,7 \quad=0,088$
$\mathrm{A}_{1,4}=(1 / 5) / 1.65$
$=0,121$
$\mathrm{A}_{2,2}=1 / 5,7$
$=0,175$
$\mathrm{A}_{3,2}=(1 / 5) / 5,7$
$=0,035$
$\mathrm{A}_{4,2}=4 / 5,7$
$=0,702$
$\mathrm{A}_{2,4}=(1 / 4) / 1,65=0,151$
$\mathrm{A}_{3,4}=(1 / 5) / 1,65 \quad=0,121$
$\mathrm{A}_{4,4}=1 / 1,65 \quad=0,606$

Lakukan perhitungan nilai rata-rata dengan cara:

$\mathrm{A}_{1}=(0,12+0,088+0,214+0,121=0,136$

$\mathrm{A}_{2}=(0,24+0,175+0,357+0,151 \quad=0,231$

$\mathrm{A}_{3}=(0,04+0,035+0,071+0,121=0,067$

$\mathrm{A}_{4}=(0,60+0,702+0,357+0,606=0,566$

Maka hasil lengkap perhitungan adalah sebagai berikut:

$$
\mathrm{A}=\left\{\begin{array}{lllll}
0,12 & 0,09 & 0,21 & 0,12 & 0,136 \\
0,24 & 0,18 & 0,36 & 0,15 & 0,231 \\
0,04 & 0,04 & 0,07 & 0,12 & 0,067 \\
0,60 & 0,70 & 0,36 & 0,61 & 0,566
\end{array}\right\}
$$

Sehingga nilai vektor bobot yang didapat adalah:
$\mathrm{W}=0,136$;
0,231 ;
0,067
0,566

2. Mengecek Konsistensi

\begin{tabular}{|c|c|c|c|c|c|c|}
\hline 1,00 & 0,50 & 3,00 & 0,20 & & 0,136 & $=$ \\
\hline 2,00 & 1,00 & 5,00 & 0,25 & $\mathrm{x}$ & 0,231 & $=$ \\
\hline 0,33 & 0,20 & 1,00 & 0,20 & & 0,067 & $=$ \\
\hline 00 & 4,00 & 5,00 & 1,00 & & 0,566 & $=$ \\
\hline
\end{tabular}

Menghitung $(\mathrm{A})\left(\mathrm{W}^{\mathrm{T}}\right)$

$(\mathrm{A})\left(\mathrm{W}^{\mathrm{T}}\right)=$

3. Menghitung $t$ :

$\mathrm{t}=1 / 4(0,5654 / 0,136+0,9789 / 0,231+0,2717 / 0,067+2,5040 / 0,566)$

$=1 / 4(16,88)=4,22$ 
4. Menghitung index konsisten dengan rumus:

$$
\begin{aligned}
\mathrm{CI} & =(\mathrm{t}-\mathrm{n}) /(\mathrm{n}-1) \\
& =(4,22-4) /(4-1) \\
& =0,073
\end{aligned}
$$

5. Menghitung Rasio Konsistensi:

Untuk n=4, diperoleh RI4 $=0.90$ (Daftar Nilai Random Index Saaty)

Rasio Konsistensi $\quad=\mathrm{CI} / \mathrm{RI}_{4}$

$$
\begin{aligned}
& =0,073 / 0,9 \\
& =0,081
\end{aligned}
$$

Rasio konsistensi $(0.081)<=0.1$ maka matriks A cukup konsisten.

\section{b. Menghitung alternatif terbaik}

Berdasarkan tabel 4.2, jumlah alternatif calon peserta siswa pada Jenjang Sekolah Dasar Di Kecamatan Gunung Maligas untuk kelas 4 sebanyak 4 siswa yakni: Alesha Dafiyah Siahaan (Peserta_1), Alisya Devi Ardyan (Peserta_2), Anisa Ramdhani (Peserta_3) dan Asyanna Siringo Ringo (Peserta_4).

1. Menghitung nilai untuk tujuan pada kriteria Pengalaman Olimpiade $=\mathrm{K} 1$

Pengambil keputusan memilih dan membandingkan setiap alternatif berdasarkan nilai perbandingan berpasangan sehingga didapatkan matriks dibawah.

$$
\mathrm{A}_{1}=\left\{\begin{array}{cccc}
1 & \frac{1}{2} & 5 & \frac{1}{3} \\
2 & 1 & 7 & \frac{1}{2} \\
\frac{1}{5} & \frac{1}{7} & 1 & \frac{1}{9} \\
3 & 2 & 9 & 1
\end{array}\right\}
$$

Setelah itu dinormalisasi:

$$
\mathrm{A}_{1}=\begin{array}{lllll}
0,161 & 0,137 & 0,227 & 0,171 & 0,174 \\
0,322 & 0,275 & 0,312 & 0,257 & 0,293 \\
0,320 & 0,040 & 0,045 & 0,057 & 0,044 \\
0,484 & 0,549 & 0,409 & 0,514 & 0,489
\end{array}
$$

Sehingga didapatkan $S_{11}=0,174 ; S_{12}=0,293 ; S_{13}=0,044 ; S_{14}=0,049$;

2. Menghitung nilai untuk tujuan pada kriteria $\mathrm{K} 2=$ Intelligensi

$$
\mathrm{A}_{2}=\left\{\begin{array}{llll}
1 & 9 & 5 & 2 \\
\frac{1}{9} & 1 & \frac{1}{9} & \frac{1}{9} \\
\frac{1}{5} & 9 & 1 & \frac{1}{2} \\
\frac{1}{2} & 9 & 2 & 1
\end{array}\right\}
$$

Setelah itu dinormalisasi:

$$
\mathrm{A}_{2}=\begin{array}{lllll}
0,552 & 0,321 & 0,616 & 0,554 & 0,511 \\
0,061 & 0,036 & 0,014 & 0,031 & 0,035 \\
0,110 & 0,321 & 0,123 & 0,138 & 0,173 \\
0,276 & 0,321 & 0,217 & 0,277 & 0,280
\end{array}
$$

3. Dari langkah diatas dihasilkan matriks skor setiap alternatif terhadap setiap kriteria.

\begin{tabular}{lllll}
\hline & K1 & K2 & K3 & K4 \\
\hline Peserta_1 & 0,174 & 0,511 & 0,212 & 0,051 \\
Peserta_2 & 0,293 & 0,035 & 0,048 & 0,397 \\
Peserta_3 & 0,044 & 0,173 & 0,422 & 0,192 \\
Peserta_4 & 0,489 & 0,280 & 0,319 & 0,360 \\
\hline
\end{tabular}


Vector bobot kriteria yang sudah diperoleh pada perhitungan sebelumnya $\mathrm{W}=$ $[0,136 ; 0,231 ; 0,067 ; 0,566]$

4. Skor total setiap alternative adalah :

$$
\begin{aligned}
& S_{1}=(0,174 \times 0,136)+(0,511 \times 0,231)+(0,212 \times 0,067)+(0,051 \times 0,566) \\
& S_{1}=0,185 \\
& S_{2}=(0,293 \times 0,136)+(0,035 \times 0,231)+(0,048 \times 0,067)+(0,397 \times 0,566) \\
& S_{2}=0,276 \\
& S_{3}=(0,044 \times 0,136)+(0,173 \times 0,231)+(0,422 \times 0,067)+(0,192 \times 0,566) \\
& S_{3}=0,183 \\
& S_{4}=(0,489 \times 0,136)+(0,280 \times 0,231)+(0,319 \times 0,067)+(0,360 \times 0,566) \\
& S_{4}=0,356
\end{aligned}
$$

Skor Peserta_4 (S4) paling besar, maka peserta_4 merupakan alternatif terbaik berdasarkan pilihan pengambil keputusan menggunakan metode AHP.

\section{Kesimpulan}

Kesimpulan yang didapat dari penulisan skripsi ini adalah:

a. Pemilihan siswa peserta olimpiade pada jenjang sekolah dasar di Kecamatan Gunung Maligas dengan menggunakan AHP dapat diterapkan dan diimplementasikan dengan aplikasi web dimana kriteria penilaian yang digunakan antara lain: $\mathrm{K} 1$ = Pengalaman Olimpiade, $\mathrm{K} 2$ = Intelligensi, $\mathrm{K} 3$ = Kemampuan Akademik (Nilai Rapor IPA atau Matematika) dan K4 = Kemampuan Olimpiade.

b. Hasil dari penelitian menggunakan metode $A H P$ menunjukkan bahwa alternatif 4dengan nilai 0,356 (peringkat pertama) sebagai rekomendasi peserta siswa olimpiade.

Berdasarkan penelitian dan implementasi sistem yang dilakukan, maka diberikan beberapa saran sebagai berikut.

a. Perlu adanya evaluasi kedepan untuk menambah jumlah kriteria yang digunakan dalam mendukung proses pengambilan keputusan,

b. Ada baiknya sistem dikembangkan berbasis android, sehingga dapat lebih banyak menyediakan informasi dan lebih mudah diakses semua kalangan masyarakat,

c. Perlu adanya pengembangan lebih lanjut terhadap sistem yaitu membangun sistem yang lebih aman dan user-friendly dengan memperhatikan aspek - aspek Interaksi Manusia dan Komputer,

d. Perlu dilakukan perbandingan metode $A H P$ dengan metode SPK lainnya yang mendukung pengambilan keputusan multi kriteria dalam sistem pendukung keputusan pemilihan peserta siswa olimpiade.

\section{Daftar Pustaka}

[1] D. Novianti, I. F. Astuti, And D. M. Khairina, "Sistem Pendukung Keputusan Berbasis Web Untuk Pemilihan Café Menggunakan Metode Smart ( Simple MultiAttribute Rating Technique ) (Studi Kasus : Kota Samarinda)," In Seminar Sains Dan Teknologi Fmipa Unmul, 2016, Pp. 461-465.

[2] R. Sundari, M. Safii, D. Hartama, And Poningsih, "Optimasi Metode Ahp Dalam Menentukan Media Promosi Bagi Mahasiswa Baru Pada Stikom Tunas Bangsa," Konf. Nas. Teknol. Inf. Dan Komput., Vol. I, Pp. 322-328, 2017.

[3] S. Sundari, A. Wanto, Saifullah, And I. Gunawan, "Sistem Pendukung Keputusan Dengan Menggunakan Metode Electre Dalam Merekomendasikan Dosen Berprestasi Bidang Ilmu Komputer (Study Kasus Di Amik \& Stikom Tunas Bangsa)," Semin. Nas. Multi Disiplin Ilmu, No. X, Pp. 1-6, 2017.

[4] I. Setyaningsih, "Analisis Pemilihan Supplier Menggunakan Metode Analytic Hierarchy Process (Ahp)," J. Ilm. Tek. Ind., Vol. 10, No. 1, Pp. 7-13, 2011. 
[5] D. R. Sari, A. P. Windarto, D. Hartama, And S. Solikhun, "Sistem Pendukung Keputusan Untuk Rekomendasi Kelulusan Sidang Skripsi Menggunakan Metode Ahp-Topsis," J. Teknol. Dan Sist. Komput., Vol. 6, No. 1, P. 1, 2018, Doi: 10.14710/Jtsiskom.6.1.2018.1-6. 